
A C T A

\title{
STUDIES ON THE MUSCLE CATHEPSIN ACTIVITY OF MACKEREL
} BADANIA NAD AKTYWNOŚCIĄ KATEPSYN MIĘŚNIOWYCH MAKRELI

\author{
Institute of Marine Food Technology
}

The $\mathrm{pH}$ and temperature effects on the mackerel muscle autolysis intensity were investigated. The muscle cathepsin was isolated and purified; some properties of the purified enzyme were determined.

\section{INTRODUCTION}

Various biochemical processes inducing profoud changes in the basic muscle tissue components occur during fish storage, both fresh and frozen. The most significant changes are those associated with the protein system; they are influenced by proteolytic enzymes. The protein - splitting enzymes are specific in their activity which depends on many factors, $\mathrm{pH}$ and temperature of the environment being some of them.

In the present study the effects of $\mathrm{pH}$ and temperature on the catheptic activity during mackerel muscle autolysis were followed, the muscle cathepsin was isolated and purified and some of its properties examined.

\section{EXPERIMENTAL MATERIALS AND METHODS}

\section{Materials}

Colias mackerel, Scomber colias (Gmelin), caught in September on the North-West African shelf and appropriately preserved on board of a commercial trawler were the object of the investigations. Fishes from a 2-hour night haul were frozen. Immediately after catching the fishes were thoroughly washed and arranged on trays in a manner eliminating any possible mechanic damage on freezing. In several minutes after preparing 
the fishes, the freezing process was started in Danish freezers "Sabroe". The process lasted 170 mins, the internal temperature of the frozen block reaching ca $-20^{\circ} \mathrm{C}$. Having completed their freezing and taken them out of trays the fish blocks were glazed, packed in cartons and placed in ship's holds at $-25^{\circ} \mathrm{C}$. After $24 \mathrm{~h}$ the blocks were thoroughly glazed again and stored in the holds at $-25^{\circ} \mathrm{C}$ for 18 days. Having landed and delivered fish by a refrigerated van to the department, they were stored in a freezer at $-25^{\circ} \mathrm{C}$. The investigations began immediately after the fishes had been brought to the laboratory, i.e., after 21 days of storage.

Methods

Fish muscles autolysis was performed in a manner described in the previous paper (Fik, 1972), using the Sörensen method (Katzenellenbogen and Mochnacka, 1969) to determine the amino nitrogen increments and expressing them as percentages of the maximum increment. The enzyme extracts were prepared by the method reported in the previous paper (Fik, 1972). Proteolytic activities fo raw extracts and partly purified preparates. were determined on urea- and $\mathrm{NaOH}$ - denatured hemoglobin by the Anson method (Bergmayer, 1965). The purified cathepsin was incubated with synthetic substrates specific for cathepsins A, B and C of mammals in the conditions reported by Tallan et al. (1952). The cathepsin A activity against N-carbobenzoxy-1-glutamyl-L-tyrosine was determined by the ninhydrin method (Bailey, 1962), whereas cathepsin A and cathepsin B activities were determined with N-benzoyl-L-arginine amide and glycyl-L-tyrosine amide, respectively, by the Conway method (Johnston et al., 1950). The protein content was determined by the biuret method (Gornall et al., 1949), bovine serum crystalline albumin being used as a standard, and by the ultraviolet: absorption method. The method described by Siebert and Schmitt (1965) was applied to the cathepsin purification.

\section{DISCUSSION OF RESULTS}

Initially the influence of $\mathrm{pH}$ and temperature on the mackerel muscle autolysis rate was determined, the results being presented in Figs. 1 and 2.

The autolysis proceeded with its highest intensity at $\mathrm{pH}$ range 4.0-4.4. After the time allowed for the autolysis had been increased from 4 to 6 hours, the course of the curve did not change and the same optimal value was maintained. Fig. 1 shows the $\mathrm{pH}$ shift from 4.0 toward a more acid range resulting in a rapid decrease in the autolysis rate caused by a change in catheptic activity. On the other hand, an increase in $\mathrm{pH}$ from 4.0 toward the alkaline range brought about a relatively slow catheptic activity decrease. At $\mathrm{pH} 5.2$ after $6 \mathrm{hrs}$ of proteolysis the activity was still on the $60 \%$ level of that at $\mathrm{pH} 4.0$.

The optimal autoproteolysis temperature for the mackerel muscles is close to $40^{\circ} \mathrm{C}$ (Fig. 2). An increase from 40 to $50^{\circ} \mathrm{C}$ caused a considerable, by $60 \%$ fall in the catheptic activity. The enzymes of the fish species discussed, however, seem to be slightly more 


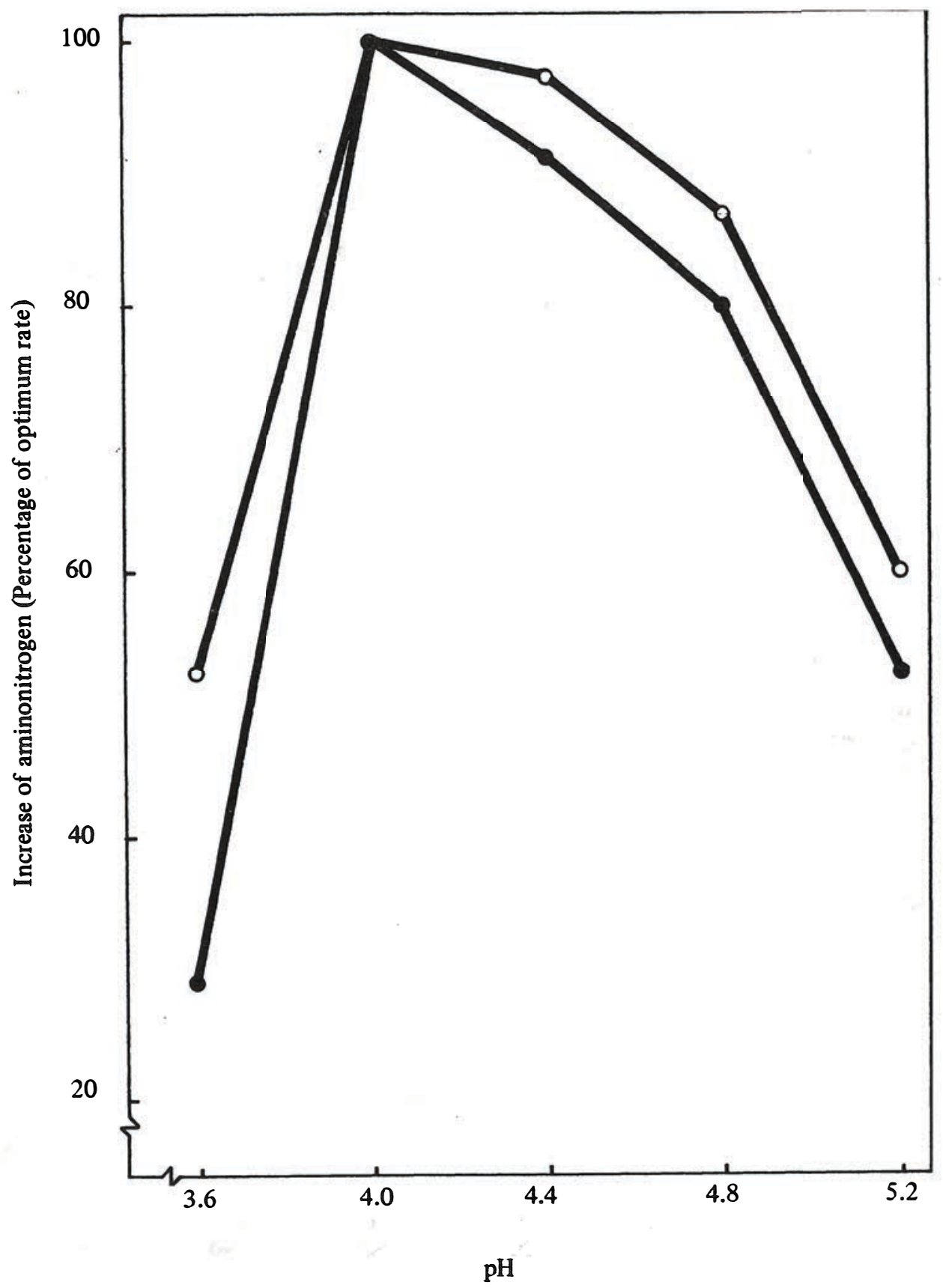

Fig. 1. Influence of $\mathrm{pH}$ on the autoproteolysis of mackerel muscle at $20^{\circ} \mathrm{C} . \bullet-\bullet-4$ hrs incubation, $c-0-6$ hrs incubation 


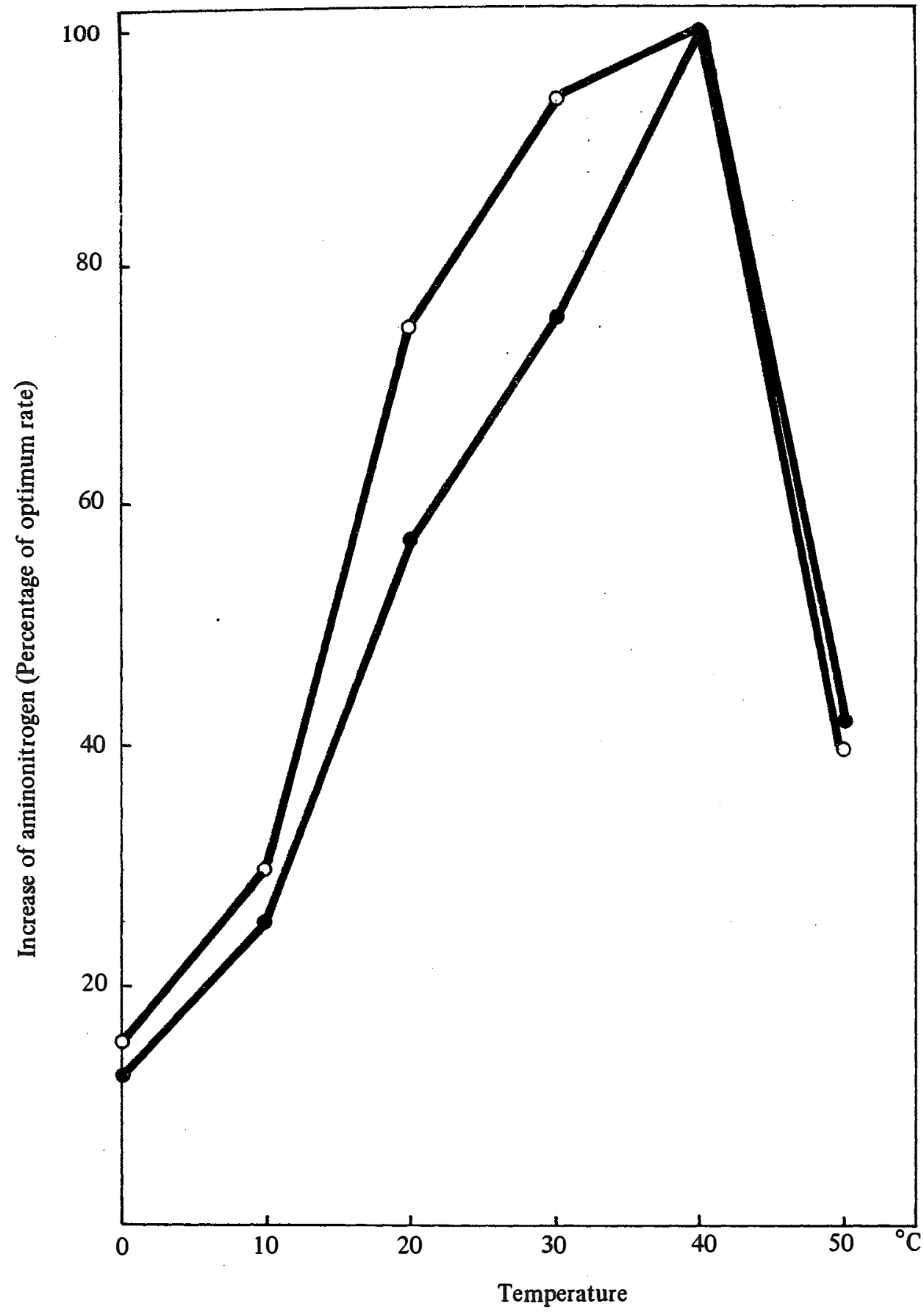

Fig. 2. Influence of temperature on the autoproteolysis of mackerel muscle at $\mathrm{pH} 4.0 . \bullet-\bullet-4$ hrs incubation, $0-0-6 \mathrm{hrs}$ incubation 


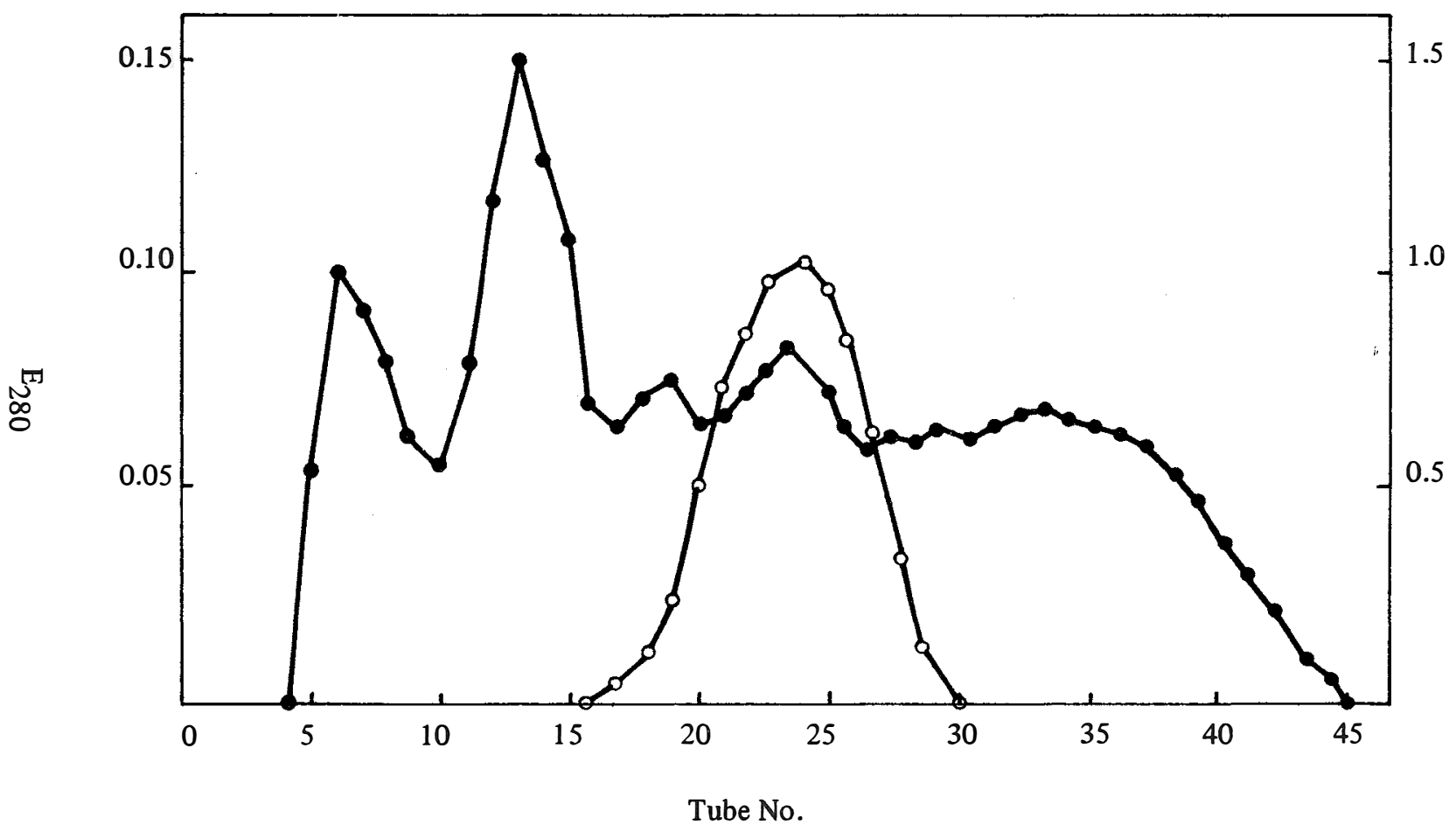

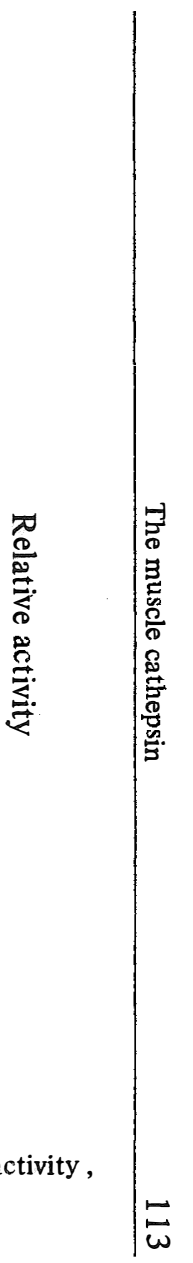

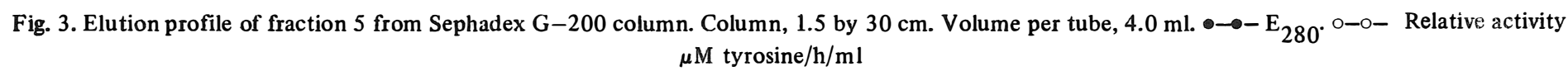




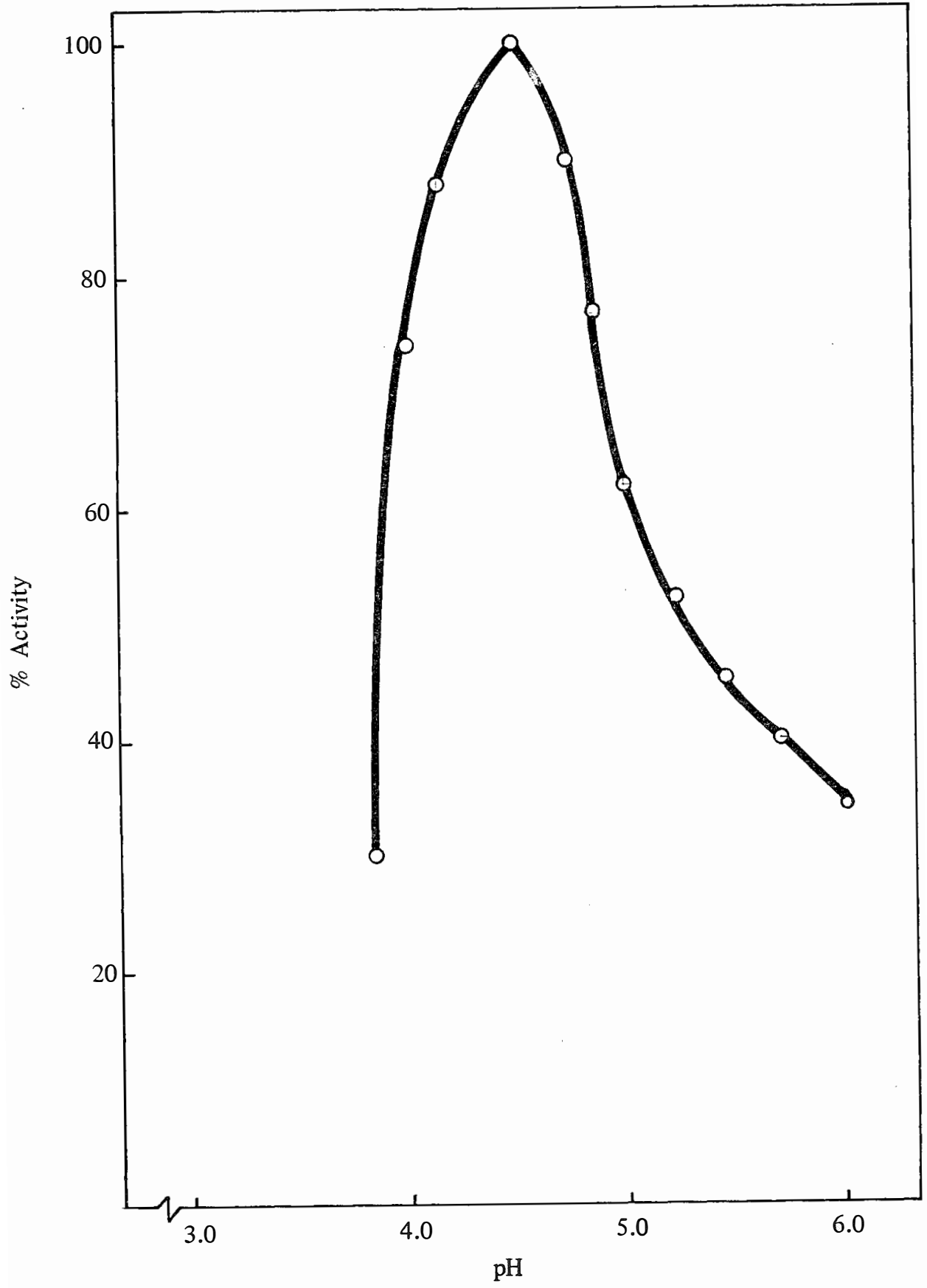

Fig. 4. Influence of $\mathrm{pH}$ on the activity of fraction 6 , at $40^{\circ} \mathrm{C}$, with denatured hemoglobin as the substrate 
Table 1

Purification of mackerel muscle cathepsin

\begin{tabular}{|c|c|c|c|c|c|c|c|}
\hline \multirow[b]{2}{*}{ Fraction } & \multirow[b]{2}{*}{$\begin{array}{l}\text { Volume } \\
(\mathrm{ml})\end{array}$} & \multicolumn{2}{|c|}{ Protein } & \multicolumn{2}{|c|}{ Activity } & \multirow[b]{2}{*}{$\begin{array}{l}\text { Purifi- } \\
\text { cation }\end{array}$} & \multirow[b]{2}{*}{$\begin{array}{l}\text { Yield } \\
(\%)\end{array}$} \\
\hline & & $\mathrm{mg} / \mathrm{ml}$ & $\begin{array}{l}\mathrm{mg} / \mathrm{frac}- \\
\text { tion }\end{array}$ & $\begin{array}{l}\mu \mathrm{M} \text { ty ro- } \\
\text { sine } / \mathrm{h} / \\
\text { fraction }\end{array}$ & $\begin{array}{c}\mu \mathrm{M} \text { tyro- } \\
\text { sine } / \mathrm{h} / \\
\mathrm{mg} \text { pro- } \\
\text { tein }\end{array}$ & & \\
\hline $\begin{array}{l}\text { 1. Crude extract }(500 \mathrm{~g} \text { of } \\
\text { the muscle) }\end{array}$ & 1260 & 26.0 & 32760 & 2653 & 0.081 & 1 & 100 \\
\hline 2. First acid-heat treatment & 1180 & 7.0 & 8260 & 2023 & 0.245 & 3.4 & 76 \\
\hline $\begin{array}{l}\text { 3. Ammonium sulfate preci- } \\
\text { pitation }\end{array}$ & 200 & 10.0 & 2000 & 1260 & 0.630 & 7.8 & 47 \\
\hline $\begin{array}{l}\text { 4. Second acid-heat treat- } \\
\text { ment }\end{array}$ & 210 & 2.0 & 420 & 1075 & 2.56 & 31.6 & 40 \\
\hline 5. Acetone precipitation & 15 & 3.2 & 48 & 451 & 9.4 & 116 & 17 \\
\hline $\begin{array}{l}\text { 6. Eluate from Sephadex } \\
\text { G-200 }\end{array}$ & 30 & 0.32 & 9.6 & 269 & 28.0 & 345 & 10 \\
\hline
\end{tabular}

resistant to denaturation changes occurring with temperature than the muscle cathepsins of horse mackerel (Fik, 1972).

Carrying on the studies, the mackerel muscle cathepsin was isolated and purified, and some of its properties examined. The enzyme was purified 345 fold with $10 \%$ yield (Table 1). The first acid treatment using $2 \mathrm{~N}$ acetic acid at $35^{\circ} \mathrm{C}$ resulted in 3.4 -fold enrichment of the enzyme. The enzyme thus obtained could be stored overnight at $0^{\circ} \mathrm{C}$ with no noticeable changes in its activity. Ammonium sulphate fractionation increased the enzyme activity 8-fold over the non-purified extract. Lyophilized enzyme preparate of the 4 th fraction maintained its activity for several months at $0^{\circ} \mathrm{C}$. Acetone fractionation yielded a 3.4-fold increase in the enzyme activity over its initial value. Pooling the highest activity fractions after the Sephadex G-200 filtration (Fig. 3), the main peak of catheptic activity was obtained. This fraction was freeze-stored for several weeks, no change in its enzymatic activity being detected. Obviously, durability of the lyophilized enzyme is unlimited.

The purified cathepsin showed a maximum activity against the denatured hemoglobin at $\mathrm{pH} 4.4$ (Fig. 4). This result is close to the $\mathrm{pH}$ optimum for purified muscle cathepsins of cod (Siebert, 1962) and hake (Fik, 1973), differing slightly from the optimum for 
purified cod spleen cathepsin (Siebert et al., 1963) and greatly deviating from the optimum for purified tuna muscle proteinase (Groninger, 1964). The $\mathrm{pH}$. optimum for the purified cathepsin is almost identical with that for the mackerel muscle autolysis (Fig. 1). The enzyme purified during the studies presented showed good hemoglobin - splitting properties but remained inactive against synthetic substrates specific for the mammalian cathepsins A, B and C. Similar results were obtained by Siebert and Schmitt (1965) and Groninger (1964) for the cod muscle cathepsin and tuna muscle proteinase, respectively. Thus the mackerel muscle cathepsin is different from the mammalian cathepsins which can be classified according to their synthetic substrates - splitting properties (Tallan et al., 1952). The classification of the cathepsin discussed could only be made basing on an appropriate standard protein decomposition. Siebert and Schmitt (1965) made an attempt to classify the cod cathepsins of muscles and spleen against insuline. However, the insuline B chain decomposition showed no different properties when compared to the cathepsins tested so far against this protein and did not allow an exact enzyme specificity classification to be made. Therefore, the intracellular occurrence and optimum activity within the acid range are still retained as classification characters of the fish proteinases catheptic nature.

The temperature coefficients, $Q_{10}$, of the purified mackerel muscle cathepsin were comprised within 1.6-2.3 when measured at $10-40^{\circ} \mathrm{C}$. Regarding the thermal lability, usually the temperature the 30-minute action of which results in a $50 \%$ enzyme inactivation, is determined. According to Siebert and Schmitt (1965) this temperature is alike for various enzymes of fish and mammalian muscles and is comprised within $42-48^{\circ} \mathrm{C}$.

\section{CONCLUSIONS}

1. The mackerel muscle cathepsin showed the optimal activity at $\mathrm{pH} 4-4.4$ and ca $30^{\circ} \mathrm{C}$.

2. The purified mackerel muscle cathepsin did not split the synthetic substrates specific for the mammalian cathepsins A, B and C.

\section{REFERENCES}

Bailey J.R., 1962: Techniques in Protein Chemistry, Amsterdam: 272.

Bergmeyer H.U., 1965: Methods of Enzymatic Analysis. Academic Press, New York and London: 808, 819.

Fik M., 1972: Optimal conditions for autolysis of jack fish muscles. Acta Ichthyologica et Piscatoria 2, 2: 113 .

Fik M., 1972: Activity of muscular cathepsins of some marine fishes. Acta Ichthyologica et Piscatoria 2, 2: 105 .

Fik M., 1973: Niektóre właściwości częściowo oczyszczonej katepsyny mięśni morszczuka. [Some properties of partly purified cathepsins of the hake muslces]. Bromat. Chem. Toksykol. 6, 2: 225 . 
Gornall A.G., Bardawill C.J., David M.M., 1949: Determination of serum proteins by means of the biuret reaction. J. Biol. Chem. 177: 751.

Groninger H.S., 1964: Partial purification and some properties of proteinase from albacore (Germo alalunga) muscle. Arch. Biochem. Biophys. 108: 175.

Johnston R.B., Mycek M.J., Fruton J.S., 1950: Catalysis of transamidation reactions by proteolytic enzymes. J. Biol. Chem. 185: 629.

Mejbaum-Katzenellenbogen W., Mochnacka I., 1969: Kurs praktyczny $\mathrm{z}$ biochemii. [The practical course of biochemistry]. PWN, Warszawa : 178.

Siebert G., 1962: Enzymes of marine fish muscle and their role in fish spoilage. Fish in Nutrition. Fishing News (Books) Ltd., London: 80.

Siebert G., Schmitt A., Träxler G., 1963: Reinigung und proteolytische Spezifitäte eines neuen Kathepsins aus Dorschmilz. Z. Physiol. Chemie 332: 160.

Siebert G., Schmitt A., 1965: Fish tissue enzymes and their role in the deteriorative changes in fish. The Technology of Fish Utilization. Fishing News (Books) Ltd., London: 47.

Tallan H.H., Jones E.M., Fruton J.S., 1952: On the proteolytic enzymes of animal tissues. Beef spleen cathepsin C. J. Biol. Chem. 194: 793.

\section{BADANIA NAD AKTYWNOŚCIĄ KATEPSYN MIĘŚNIOWYCH MAKRELI}

\section{Streszczenie}

Zbadano wpływ $\mathrm{pH}$ i temperatury na aktywność katepsyn w procesie autoproteolizy mięśni makreli. Stwierdzono, że autoproteoliza przebiegała najintensywniej w $\mathrm{pH}$ 4-4,4 i temperaturze około $40^{\circ} \mathrm{C}$. Zmiana $\mathrm{pH}$ od optimum w kierunku kwaśnym powodowała gwałtowniejszy spadek szybkości proteolizy niż w kierunku zasadowym. Podwyższenie temperatury z 40 do $50^{\circ} \mathrm{C}$ spowodowało $60 \%$ zmniejszenie aktywności katepsyn.

W dalszej kolejności wyizolowano i 345-krotnie oczyszczono katepsynę mięśniową makreli. Enzym oczyszczony wykazał optymalną aktywność w stosunku do zdenaturowanej hemoglobiny w pH 4,4. Katepsyna dobrze rozkładała zdenaturowaną hemoglobinę lecz nie rozkładała substratów syntetycznych właściwych dla katepsyn A, B i C ssaków. Różni się więc ona pod względem specyficzności od katepsyn ssaków, które można klasyfikować poprzez rozkład odpowiednich substratów syntetycznych.

M. Фик

ИССЛЕДОВАНИЯ АКТИВНОСТИ МЫШЕЧНЫХ КАТЕПСИНОВ СКУМБРИИ

$P$ P 3 ID M $\mathrm{e}$

Исследовано влияние $\mathrm{pH}$ и температуры на активность катепсинов в процессе автопротеолиза мышц скумбрии, Установлено, чтө наиболее интенсивно автопротеолиз протекал при $\mathrm{pH} 4-4,4$ при температуре около $40^{\circ} \mathrm{C}$. Отклонение $\mathrm{pH}$ от оптимума в нислотном направлении вызывало более резкое снижение скорости протеолиза, чем в щелочном направлении. Повышение температуры с $40^{\circ}$ до $50^{\circ}$ вызвало 60\%-ное снижение активности катепсинов. 
Затем был выдөлен и 245 раз очищен мышечный катөпсин скумбрии. Очищенный энзим характеризуется оптимальной активностью-по отношению к дөнатурированному гемоглобину при $\mathrm{pH}=4,4$. Катепсин хорошо расщеплял дөнатурированный гемоглобин, но не расщеплял синтетических субстратов, характерных для катепсинов A, В и С млөкопитаюци. Таким образом, он отличается по своөй специфике от катепсинов млекопитаюци, которые можно классифицировать путём расщепления соответствуюих синтөтических субстратов.

Address:

Received: 17 XI 1975 r.

Dr Mirosław Fik

Insty tut Technologii Żywności Pochodzenia Morskiego AR

71-550 Szczecin, ul. Kazimierza Królewicza 4

Polska - Poland 